\title{
INSPIREE:
}

INDONESIAN SPORT INNOVATION REVIEW

ISSN 2746-6965 (Online), 2774-2520 (Print)

Journal Homepage: https://inspiree.review/index.php/inspiree

REVEW

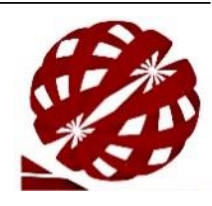

\section{Table Tennis classes at Junior High Schools utilizing the TPACK-Based Problem-Based Learning Model}

doi https://doi.org/10.53905/inspiree.v3i01.76

\author{
"Samsuddin Siregar ${ }^{1 \mathrm{labcde}}\left(\mathbb{O}\right.$, Juli Rachmadani Hasibuan ${ }^{\mathrm{labe}}$, Cindy Anggraini ${ }^{1 \mathrm{lde}}$, Aidil \\ Arifin Marpaung ${ }^{\text {labcde, }}$, Dede Yohana Marbun ${ }^{\text {labcde }}$
}

${ }^{1}$ Universitas Negeri Medan, North Sumatra, Indonesia.

\begin{abstract}
A B S TRACT
The purpose of the study. Through the application of the TPACK - based PBL model, it can improve learning outcomes in the aspect of table tennis service material skills for junior high school students.

Materials and methods. The method used is the Action Research Class method with two cycles, each cycle through the stages of planning, action, observation and reflection. The research subjects were 25 students. The data of this research is the result of learning table tennis service and analyzed by using the percentage technique of Sugiyono's theory. Results. Student learning outcomes in the aspect of skills have increased from cycle one to cycle two. aspects of service learning outcomes at the implementation stage the percentage obtained in the first cycle was only $74.3 \%$, an increase in the second cycle to $97.7 \%$. Likewise, at the final stage of cycle one, it was only $35 \%$. students who complete have increased in the second cycle to $81 \%$.

Conclusions. The TPACK-based learning problem model makes learning more meaningful and the learning outcomes of Junior High School students experience classical mastery.
\end{abstract}

ARTICLE INFO

Keywords: table tennis; problem-based learning; tpack.

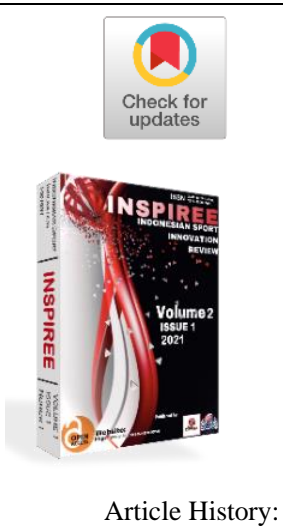

Received: November 22, 2021 Accepted: December 26, 2021

\section{INTRODUCTION}

Physical education, sports and health is one of the subjects taught in primary and secondary education (Aip Syarifuddin dan Muhadi, 1992). This subject is essentially an educational effort through the use of various physical activities to achieve the goals of national education, namely to form the character of students who are physically and mentally healthy, intelligent, intellectual and have faith, piety. In connection with these educational objectives, a health sports physical education curriculum is prepared that contains various subject matter at the basic, secondary and vocational education levels. (Kemendikbud, 2016). Through these subject matter, it is hoped that physical education can be a shield in achieving national education goals. For basic education 
(junior high school) the coverage of physical education subjects for health sports consists of; physical activity/physical fitness, athletics, games (big ball and small ball), gymnastic activities, and aquatic activities (Amri Sofan, 2013).

Various efforts have been made by teachers of physical education, sports and health to teach these materials to students. Teachers continue to innovate in various ways so that the learning process of physical education in health sports can be meaningful for students. (Samsuddin Siregar, 2020). But along with the times, the paradigm of education also changes. Education has been disrupted with the times, with the advent of information and communication technology. Then due to the development of information and communication technology at this time has changed student learning behavior, through the Android owned makes students more knowledgeable in obtaining knowledge information from various sources. So that the teacher is no longer the only source of knowledge for students. With this condition, in the future it is hoped that physical education teachers in sports and health should also be more innovative and creative in packaging learning, especially in various models, approaches, media and learning environments that will be used. (Samsuddin Siregar, 2008). However, in the face of the development of the digital era of information and communication technology today, not a few teachers of physical education and sports health (PJOK) are overwhelmed in developing meaningful learning for students. (Prahmana et al., 2021). One of the crucial issues at this time is that PJOK teachers are less capable of integrating education with technology in the learning process. (Smaldino,Sharon. Lowter,Deborah. Russel, 2011). Apart from that, PJOK teachers are also less capable in packaging the HotS-based learning process. This is also the case for PJOK teachers at Junior High Schools, Deli Serdang Regency, North Sumatra, Indonesia (Abdul Majid, 2005). This is also the case for PJOK teachers at Junior High Schools, Deli Serdang Regency, North Sumatra, Indonesia.

Observations have been carried out in one of the Sumatran Junior High Schools in Deli Serdang, Interviews were conducted with the teachers, related to the implementation of learning (methods, models, media) that have been used so far in teaching PJOK material. The results of observations prove that the learning carried out by PJOK teachers is still teacher-centered. The teacher's role is still more dominating 
than the students. Students act in accordance with the teacher's directions. This way of learning is currently less attractive to students. In the current era, students are the millennial generation who have a perspective that they will be able to do everything, the desire to try and the desire to explore something they want is very high. This happens because today's students have many sources of knowledge so that their thinking skills are much more complex.

Learning for these students must be able to provide a process that can involve the role of student dominance, learning that is able to develop critical and creative power, and learning that is able to develop student communication and collaboration. To achieve this, it requires innovation and creativity from a teacher both related to models and learning media. The learning model is one of the important elements that must be mastered by teachers in implementing the physical education, sports and health learning process. Likewise, the role of learning media is no less far compared to the learning model. The learning models and media used by the teacher must be able to develop critical thinking and creativity, and be able to develop communication and collaboration for each student. One of the learning models that are seen as having the above is the Problem Base Learning model.

Trianto (2010) define, Problem Based Learning (PBL) learning model is a learning model that is based on many problems that require authentic investigations, namely investigations that address real problems. Through this model, students will be given various cases to interpret the material (Purwanto \& Suharjana, 2017). And various cases that exist the students are directed to find a solution. (Wijaya et al., 2020). Then this model is very requisite with groups, through groups of students will work together to solve existing problems. (Nurul Fauzi, 2017). The implementation of this model follows at least 5 paths, and these paths must be carried out systematically from beginning to end. The flow/steps described below are the steps quoted from the book. (Trianto, 2012). The five steps are: first, the process of orienting students to problems. At this stage the teacher explains the learning objectives, explains the necessary logistics, motivates students to engage in problem solving activities, and poses problems. The second stage is to organize students. At this stage the teacher divides students into groups, helps students define and organize learning tasks related to problems. The 
third stage, guiding individual or group investigations. At this stage the teacher encourages students to collect the required information, carry out experiments and investigations to get explanations and problem solving. The fourth stage, developing and presenting the results. At this stage, the teacher assists students in planning and preparing reports, documentation, or models, and helps them share tasks with their friends. The fifth stage, analyzing and evaluating the process and results of problem solving. At this stage the teacher helps students to reflect or evaluate the process and results of the investigations they are conducting.

Based on the advantages and benefits of this model, the researcher believes that this model is a solution to the problems faced by PHYSICAL EDUCATION, SPORTS AND HEALTH teachers in Junior High Schools, namely to overcome learning so far the teacher is the dominant one, then through this model students will dominate in PJOK learning activities. This model will be applied in table tennis material, the reason for choosing this material is because table tennis is one of the most popular PJOK materials for students but is also the most difficult material for them to master. It is known that based on observations made by students when they play table tennis, out of 35 students, only 5 can play table tennis. Thus, based on the description above, the researcher wants to conduct a study, namely the application of the TPACK-based PBL model in table tennis material for junior high school students in Deli Serdang district, North Sumatra.

\section{MATERIALS AND METHODS}

\section{Study Participants}

This action research was conducted on public junior high school students in the Deli Serdang district of North Sumatra, Indonesia.

\section{Study Organization}

This research uses the class action method (Action Class). The steps taken by this method include: Planning, Action, Observing, and Reflecting (Maksum, 2012). The first step is Planning, at this stage the teacher plans and prepares for the needs needed during action, such as: First, preparation of learning program plans, media, schedule, assessment, subject, class, and licensing. The second step is Action, at this stage is the stage of implementing the lesson plan that has been designed or that should be carried out in the learning process of PJOK on table tennis material. At this stage the teacher must collaborate with other teachers or observers who are determined for the purpose of observing the process of implementing learning. The third step is Observing, this 
Table Tennis classes at Junior High Schools utilizing the TPACK-Based Problem-Based Learning Model.

stage is the activity of observing learning activities from the beginning to the end of the implementation. At this stage the observer must use the observation sheet that has been prepared earlier. The fourth step is Evaluation and Reflection, at this stage the activities carried out are conducting evaluations to see whether the actions taken result in better changes in student learning outcomes. Then the results of the evaluation are reflected in order to get feedback related to the action. The focus of reflection on the action process is how the teacher teaches, whether it is in accordance with the design, whether the media used is optimal, whether the students are active and happy. This can be seen from the beginning to the end of the lesson. The results of the reflection will be used as a basis for designing learning to stage 2 (cycle II). The implementation of the research is carried out through the Planning flow, at this stage the teacher plans and prepares the needs needed during the Action, such as: Learning Program Plan, media, schedule, assessment, subject, class, and permissions. Action, at this stage is the stage of implementing the learning plan that has been designed or should be carried out in the learning process of PJOK table tennis material. This stage the teacher must collaborate with other teachers or observers who are determined for the purpose of observing the learning implementation process. Observing, this stage is the activity of observing learning activities from the beginning to the end of implementation. At this stage the observer must use the observation sheet that has been prepared earlier. Evaluation and Reflection, at this stage the activities carried out are conducting evaluations to see whether the actions taken result in better changes in student learning outcomes. Then the results of the evaluation are reflected in order to get feedback related to the action. The focus of reflection on the action process is how the teacher teaches, whether it is in accordance with the design, whether the media used is optimally used, whether students are active and feel happy. This can be seen from the beginning to the end of the lesson. The results of the reflection will be used as a basis for designing learning to phase 2 (cycle II). Then, to find out the results of the activities carried out, data processing was continued (Sugiyono, 2016).

\section{RESULTS}

Cycle 1

Planning Phase. Before learning is carried out, the researcher first prepares learning tools in the form of Learning Program Plans, learning media, and learning 
Table Tennis classes at Junior High Schools utilizing the TPACK-Based Problem-Based Learning Model.

assessment tools. Then after the device is prepared, then coordinate with the partner. Stage of Implementation (Action). The implementation is carried out in accordance with the lesson plans that have been prepared, starting from the preliminary, core and closing stages of the Observation and Evaluation learning. The implementation stage went smoothly, based on observations from observers, it concluded that the entire series of tasks for the teacher was carried out well, when opening the lesson the teacher had carried it out according to plan and a small number of students could demonstrate their role as active students. However, there are several things that become the focus of attention in cycle 1, namely the teacher still has difficulties in managing the group of students at the time of observation, so most of the students in the group are less active. Then, at the end of the lesson, an assessment is carried out to see the impact of the learning carried out on the skill aspect. The results of the evaluation based on the data from the assessment of cycle 1 can be seen in the following diagram.

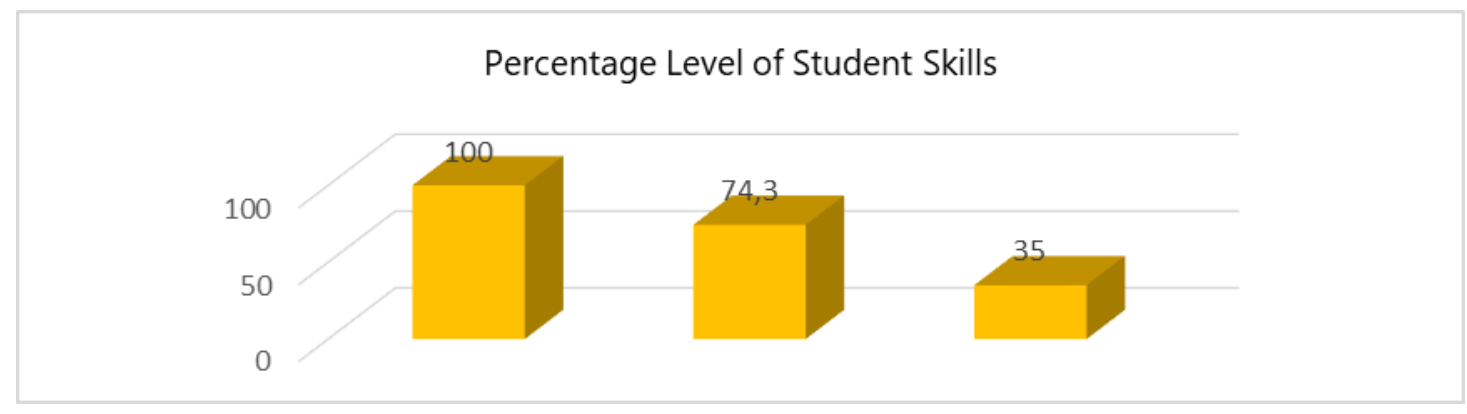

Figure 1. Percentage Diagram of Student Skill Level Cycle 1

Based on the diagram above, in general, student learning outcomes in terms of skills can not be said to be good. Especially in the service skills at the implementation stage, the percentage obtained was only $74.3 \%$ and the final stage was $35 \%$. From this percentage data, it can be concluded that the students' skills still need to be improved. To analyze the obstacles and plans that were designed not applied during the action. So that in the next lesson, alternative solutions can be given to run optimally. Based on the results of the evaluation and observation of the implementation of the first cycle of learning, there are 3 things that are the main obstacles, causing the students' basic technical skills to serve students are still not good; First, the teacher still had difficulties in managing the group of students at the time of observation, so that some students in the group were less active. The two learning systematics given by the teacher made the students still confused so that some groups were not optimal in communicating 
their creative ideas. Third, because Covid-19 made the time allocated for Limited Faceto-Face Learning (PTMT) only 40 minutes, the existing learning stages were not maximally applied. Various problems that occurred in the first cycle, so to find alternative solutions, the researchers together with the team and accompanying lecturers had discussions. The results of the discussions that have been carried out are for case 1 the teacher must group students who have skills in each group, then in the case of two teachers at the beginning of learning, they must more clearly convey information about the stages of learning that will be carried out starting from the introduction to closing, in the third case the time during implementation is added so that the model in the RPP can be applied.

Cycle 2

Planning Phase. The implementation of learning in this cycle is an improvement from the problem of obstacles faced in cycle 1 . And starting learning in cycle II, the teacher carries it out as was done in cycle I, namely before learning is carried out the teacher first prepares learning tools that have been repaired and are ready to be implemented, namely in the form of RPP, learning media, and learning assessment tools. Then, after the equipment is prepared, then coordinate with the civil servant teacher (SMP Negeri 2 Percut Sei Tuan, Deli Serdang Regency). 2. Implementation Phase (Action), Implementation is carried out in accordance with the lesson plans that are prepared. 3. Observation and Evaluation, The implementation stage of the second cycle went smoothly, at this stage the observer continued to observe to ascertain whether there were still problems. Based on the observations from the observers, it was stated that the entire series of tasks for the teacher was carried out well in accordance with the cycle II learning design, at the preliminary stage the teacher had implemented it according to the plan and the students were able to show their role as active students. The implementation of the learning model (PBL) is implemented and integrated with TPACK well. Then, at the end of the lesson, an assessment is carried out to see the impact of the learning carried out on the skill aspect. The evaluation results based on the data from the second cycle of assessment can be seen in the following diagram. 


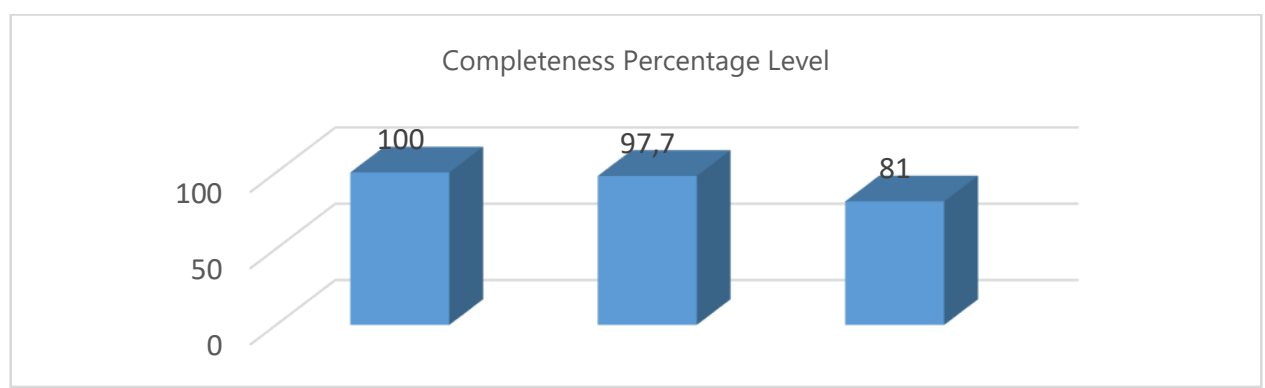

Figure 2. Diagram of Student Skill Level Percentage in Cycle II.

Based on the diagram above, in general, student learning outcomes in the skills aspect have increased from cycle 1. \%. Likewise, at the final stage of the first cycle, only $35 \%$ of students who completed experienced an increase to $81 \%$. Increasing the percentage data, it can be concluded that the problem model based on TPACK-based learning makes learning more meaningful and the learning outcomes of class IX students of SMP Negeri 2 Percut Sei Tuan Deli Serdang, North Sumatra, experience classical mastery. The results of the evaluation and observation of the implementation of the second cycle of learning are the core that is reflected. Basically the implementation of cycle II has been going well. When viewed from the aspect of the model applied, it is proven that the PBL model has been able to provide a learning experience for students and student learning outcomes have also increased. The results obtained are certainly inseparable from the improvements made to the constraints faced in cycle I.

\section{DISCUSSION}

This research is the application of a problem-based learning model based on Technological Pedagogical Content Knowledge (TPACK) in learning physical education for health sports on table tennis service material. The research was carried out using the classroom action research method as much as two cycles. Cycle I is the first action given to students, the stages of action taken in the cycle starting from the planning, implementation, observation and reflection stages. Likewise, in the second cycle, the four stages were also passed. As is known from the research results that have been found that in the first cycle the application of the learning model went quite well even though there were still obstacles that resulted in the process not being optimal to make students active as a whole. Then in the second cycle the application of the learning 
Table Tennis classes at Junior High Schools utilizing the TPACK-Based Problem-Based Learning Model.

model went well and there were no obstacles that resulted in the process not being optimal, so that in the second cycle the students were very active overall. Likewise, the learning outcomes seen from the skills aspect in cycle II are better than learning outcomes in cycle I.

The increase in learning outcomes from cycle one to cycle two, of course, cannot be separated from the problem base learning model of learning physical education in health sports on table tennis service material makes students more active in learning, this model makes students have a big role in determining the choice of activities. Learning always begins with raising problems based on the phenomena that occur, assignments, carried out by students through group analysis. The existence of a problem becomes a matter of discussion either in groups or not. After the group has done the tasks, the group team then compiles a report and presents it. Students in going through the stages of the model feel motivated, serious and collaborative in the teaching team. Furthermore, learning with the concept of Technological Pedagogical Content Knowledge makes it easier for students to listen to the service material displayed through learning media (Ayuni et al., 2020), when students as a team watch the video, different perceptions emerge between each group and are recorded on the paper provided. This condition makes students think to communicate the results of the analysis. Then through the video, students also in groups analyze how to perform the basic movement patterns of table tennis service both in practice and in games. Then the model that is applied to students feels a lot of convenience and students are satisfied.

Expressions of experts with various views regarding the model of the problem base learning in learning (Bosica et al., 2021). (Barbieri et al., 2020) This model is a model whose learning activities are student-centred, students work and think independently to analyze the various materials provided, in this case the teacher is a facilitator. When students are given various problems related to the material, going through these problems makes each group look for various sources to find alternatives to overcome these problems, as well as study groups make students share their respective ideas, and the differences in ideas they have to discuss to choose one idea. the best way to solve the problem at hand (Kok et al., 2021). Then the stage of 
Table Tennis classes at Junior High Schools utilizing the TPACK-Based Problem-Based Learning Model.

presenting the results of discussion and reflection makes students feel appreciated in front of other students' friends and in front of the teacher. This learning situation allows students to experience real learning, so students do not just listen to lectures and observe the teacher. It is different with the PBL learning model, in the process it can activate student performance both individually and in groups, so that student problems related to low student learning outcomes in the skills aspect can be overcome through the PBL model which is integrated with TPACK elements.

\section{CONCLUSION}

Based on the results of research and data analysis conducted, it can be concluded that the application of the TPACk-based problem base learning model can provide a meaningful learning process for students of SMP Negeri 2 Percut Sei Tuan and can also improve table tennis learning outcomes in technical skills aspects. Thus, through the results of this study, it was informed to the teacher that integrating the problem base learning model with TPACK was suitable for the learning process of Physical Education, Sports and Health.

\section{CONFLICT OF INTEREST}

There are 2 obstacles in the implementation of this research, namely the limited time allocated for Physical Education, Sports and Health learning (40 minutes), this happens because education in Indonesia is still implementing limited face-to-face learning (Covid-19) and the second is seen from the field constraints. table tennis is limited so that students are not optimal in doing it.

\section{ACKNOWLEDGEMENT}

This research was supported by the Universitas Negeri Medan and Universitas Pendidikan Indonesia. For this reason, I would like to thank the rector and head of the Community Service Research Institute for their moral and material support so that this research can be carried out properly.

\section{REFERENCES}

Abdul Majid. (2005). Perencanaan Pembelajaran (Mengembangkan Kompetensi Guru). Remaja Rosdakarya.

Ahmad Pratama, S. (2021). Impact of Shadow Training on the Ability of Push Forward

Punch Techniques in Table Tennis. INSPIREE: Indonesian Sport Innovation Review, 
2(1), 08-16. https://doi.org/10.53905/inspiree.v2i1.29

Aip Syarifuddin Dan Muhadi. (1992). Pendidikan Jasmani Dan Kesehatan. Departemen Pendidikan Dan Kebudayaan. Indonesia.

Amri Sofan. (2013). Pengembangan Dan Model Pembelajaran Dalam Kurikulum 2013. Prestasi Pustakaraya.

Ayuni, N., Zubainur, C. M., \& Abidin, T. F. (2020). Penerapan Tpack Dan Problem-Based Learning Model Untuk Meningkatkan Kemampuan Berpikir Kritis Siswa. Jurnal Peluang, 8(1), 48-54. Https://Doi.Org/10.24815/Jp.V8i1.20665

Azari, A., \& Zulkifli. (2020). Action Reasearch: Kemampuan Gerakan Radslag Melalui Metode Bagian Dalam Meningkatkan Hasil Belajar Senam: Radslag Movement Ability Through Part Methods In Improving Gymnastics Learning Outcomes. INSPIREE: Indonesian Sport Innovation Review, 1(1), 57-70. https://doi.org/10.53905/inspiree.v1i1.7

Barbieri, G., Sanchez-Londoño, D., Cattaneo, L., Fumagalli, L., \& Romero, D. (2020). A Case Study For Problem-Based Learning Education In Fault Diagnosis Assessment. Ifac-Papersonline, 53(3), 107-112. Https://Doi.Org/10.1016/J.Ifacol.2020.11.017

Bosica, J., Pyper, J. S., \& Macgregor, S. (2021). Incorporating Problem-Based Learning In A Secondary School Mathematics Preservice Teacher Education Course. Teaching And Teacher Education, 102, 103335. Https://Doi.Org/10.1016/J.Tate.2021.103335

Kemendikbud. (2016). Permendikbud 21 Dan 24 Tahun 2016. Kemendikbud.

Kok, M., Kal, E., Van Doodewaard, C., Savelsbergh, G., \& Van Der Kamp, J. (2021). Tailoring Explicit And Implicit Instruction Methods To The Verbal Working Memory Capacity Of Students With Special Needs Can Benefit Motor Learning Outcomes In Physical Education. Learning And Individual Differences, 89(May 2020), 102019. Https://Doi.Org/10.1016/J.Lindif.2021.102019

Maksum, A. (2012). Metodologi Penelitian Dalam Olahraga. Unesa University Press.

Nurul Fauzi, L. H. L. (2017). Penerapan Model Movement Problem Based Learning 
Table Tennis classes at Junior High Schools utilizing the TPACK-Based Problem-Based Learning Model.

Soccer Like Implementation Of Movement Problem Based Learning Model On

Soccer-Like Games Abstracts Keyword: Movement Problem Based Learning Model , Soccer Pendidikan Jasmani Merupakan Suatu Proses Pembelaja. 1(1), 85-93.

Onny Siagian, A. (2021). The Impact of Jigsaw-Type Cooperative Learning and Learning Motivation on Learning Achievement Sports Physiology at Universitas Bhayangkara. INSPIREE: Indonesian Sport Innovation Review, 2(1), 42-51. https://doi.org/10.53905/inspiree.v2i1.31

Pardilla, H. (2021). Physical Fitness and Learning Achievement Academic in Children Aged 10-12 years . INSPIREE: Indonesian Sport Innovation Review, 2(2), 165 of 175. https://doi.org/10.53905/inspiree.v2i2.51

Prahmana, R. C. I., Hartanto, D., Kusumaningtyas, D. A., Ali, R. M., \& Muchlas. (2021). Community Radio-Based Blended Learning Model: A Promising Learning Model In Remote Area During Pandemic Era. Heliyon, 7(7), E07511. Https://Doi.Org/10.1016/J.Heliyon.2021.E07511

Purwanto, D. D., \& Suharjana, S. (2017). Pengembangan Model Pembelajaran Pengenalan Teknik Dasar Tenis Meja Untuk Siswa Sd Kelas Atas. Jurnal Keolahragaan, 5(2), 133. Https://Doi.Org/10.21831/Jk.V5i2.6419

Rizky, V. ., Damanik, S. ., \& Siregar, S. (2021). Inclusion Teaching Style in Improving Learning Outcomes of Forehand Drive Table Tennis in Junior High School. INSPIREE: Indonesian Sport Innovation Review, 2(1), 52-71. https://doi.org/10.53905/inspiree.v2i1.33

Samsuddin Siregar. (2008). Perbedaan Pengaruh Metode Mengajar Dan Kemampuan Gerak Terhadap Keterampilan Teknik Dasar Bermain Bolavoli. Universitas Sebelas Maret.

Samsuddin Siregar. (2020). Efektivitas Model Pembelajaran Berbasis Permainan Dalam Meningkatkan Keterampilan Forehanddrivemahasiswa. Jurnal Ilmu Keolahragaan, 19(1), 54-62. https://doi.org/https://doi.org/10.24114/jik.v19i1.18455

Smaldino,Sharon. Lowter,Deborah. Russel, J. D. (2011). Teknologi Pembelajaran dan Media untuk Belajar. Kencana Prenada Media Group. 
Sugiyono. (2016). Metode Penelitian dan Pengembangan. CV.Alfabeta.

Trianto. (2012). Mendesain Model Pembelajaran Inovatif-Progresif.

Wijaya, T. T., Murni, S., Purnama, A., \& Tanuwijaya, H. (2020). Pengembangan Media Pembelajaran Berbasis Tpack Menggunakan Hawgent Dynamic Mathematics Software. Journal of Elementary Education, 03(03), 3. 


\section{APPENDIX}

\section{Information About The Authors:}

\section{Dr. Samsuddin Siregar, S.Pd, M.Or :}

Email: samsuddinsiregar@ unimed.ac.id; OrchidId: https://orcid.org/0000-00024557672X; Scopus AuthorId=57211562309; Program Studi Pendidikan Jasmani Kesehatan Dan Rekreasi

Fakultas Ilmu Keolahragaan Universitas Negeri Medan; Address: Jalan William Iskandar Pasar V, Medan Tembung, Medan, Sumatera Utara, 20221, Indonesia.

\section{Juli Rachmadani Hasibuan}

Email: julirachma@gmail.com; Universitas Negeri Medan; Address: Jalan William Iskandar Pasar V, Medan Tembung, Medan, Sumatera Utara, 20221, Indonesia.

\section{Cindy Anggraini}

Email: cindyanggrainy097@gmail.com; Universitas Negeri Medan; Address: Jalan William Iskandar Pasar V, Medan Tembung, Medan, Sumatera Utara, 20221, Indonesia.

Aidil Arifin Marpaung,

Email: aidilarifinmarpaung@gmail.com; Universitas Negeri Medan; Address: Jalan William Iskandar Pasar V, Medan Tembung, Medan, Sumatera Utara, 20221, Indonesia.

Dede Yohana Marbun

Email:yohanabarus02@gmail.com; Universitas Negeri Medan; Address: Jalan William Iskandar Pasar V, Medan Tembung, Medan, Sumatera Utara, 20221, Indonesia. 